\title{
RELATION AMONG MANAGERS, TEACHERS AND SCHOOLS AT STATE SCHOOLS IN TURKEY: SHARED LEADERSHIP, JOB SATISFACTION, ORGANIZATIONAL TRUST
}

\author{
Necati Çobanoğlu ${ }^{\mathrm{i}}$ \\ orcid.org/0000-0002-8469-2352 \\ Malatya Metropolitan Municipality, \\ Malatya, Turkey
}

\begin{abstract}
:
Within organizations in which leadership is shared with staff, staffs tend to develop positive feelings against both themselves and their organizations. At this study it is aimed at analyzing the level of shared leadership of the schools in terms of the teachers' perception; measurement of job satisfaction and organizational trust levels of the teachers; and settling the relationship among these variables. Additionally, it has been also tried to determine that whether shared leadership level at primary schools can predict job satisfaction and organizational trust of the teachers. The study is a research designed as relational survey method. Data of the research have been gathered from 476 teachers working at the primary schools during 2019-2020 Academic year in Central Malatya. Data have been gathered through Shared Leadership Scale, Job Satisfaction Scale and Organizational Trust Scale. For the analysis of the data, t-test, ANOVA test, correlation and regression analysis have been made. In compliance with the results of the research, levels of shared leadership, job satisfaction and organizational trust at primary schools are high. Shared leadership at primary school predicts job satisfaction and organizational trust of the teachers in a positive and significant manner.
\end{abstract}

Keywords: leadership, shared leadership, job satisfaction, organizational trust, collaboration

\section{Introduction}

It is a well-accepted fact that leadership is important for organizations for developing effective processes, obtaining fruitful outcomes and achieving their goals (Tengilimoğlu, 2005). For classical leadership approach there is a leader who performs all these processes and other employees follow him or her. (Bennett, Wise, Woods and Harvey, 2003). In recent years, sharing of leadership among employees instead of its concentration in just

i Correspondence: email necaticobanoglu@gmail.com 
one person has gradually come into question (Baloğlu, 2011; Gosling, Bolden and Petrov, 2009). One of the leadership types which have emerged as a result of this idea is shared leadership. Increase in the number of studies on shared leadership also indicates the importance of the issue (Spillane, Camburn \& Pareja, 2007; Korkmaz and Gündüz, 2011; Kösem, 2018; Kılınç, 2013; Işık, 2018; Hulpia, Devos, Rosseel \& Vlerick, 2012; Aydoğan, 2018; Aslan and Ağıroğlu Bakır; 2015; Uslu and Beycioğlu, 2013).

\section{Literature Review}

\subsection{Shared Leadership}

Study of shared leadership within literature is of long standing. The term has first been discussed by Gibb (1954) and Katz and Kahn (1966) indirectly. Main studies have been held by Firestone (1996) and Weiss and Cambone (1994) in 1980s and 1990s. Shared leadership has been named variant terms within the literature. Concepts od "distributed leadership", (Oğuz, 2013; Y1lmaz and Turan, 2015), "distributing leadership" (Hulpia, Devos and Rosseel, 2009; Davis, 2009; Taşdan and Oğuz, 2013; Korkmaz and Gündüz, 2011; Baloğlu, 2011; Özdemir, 2012), and "sharing leadership" (Korkmaz, 2011) have been used on lieu of "shared leadership". However, most scholars prefer the concept of "shared leadership". (Perry, Pearce, Sims, 1999; Duignan \& Bezzina, 2006; Wood, 2005; Beycioğlu, 2009; Bostanc1, 2012; Yılmaz, 2013; Ağıroğlu Bakır and Aslan, 2014; Özer and Beycioğlu, 2013; Aslan and Ağıroğlu Bakır, 2015). Shared leadership is mostly studied in order to determine its level in educational institutions (Spillane, Camburn \& Pareja, 2007; Korkmaz and Gündüz, 2011; Kösem, 2018; Kılınç, 2013; Işı1, 2018) and find out its correlation with organizational loyalty (Hulpia, Devos, Rosseel \& Vlerick, 2012; Aydoğan, 2018; Aslan and Ağıroğlu Bakır; 2015; Uslu and Beycioğlu, 2013). Apart from these two variables, it is studied in order to determine its effect on academic success (Davis, 2009; Seashore Louis, Dretzke \& Wahlstrom, 2010), job satisfaction, cooperation, organizational change, teacher efficiency (Hulpia and Devos, 2009; Oldaç, 2016; Harris \& Spillane, 2008; Grant, 2011; Ali \& Yangaiya, 2015).

Bolden et al (2009) have addressed three basic characteristics of shared leadership: 1. Leadership is the common characteristic of the group and is formed through interaction of group members. 2. It does not exist strict boundaries of leadership 3. Leadership practices are diversified by whole employees. These characteristics make shared leadership dynamic, interactionist and holistic, constantly. It is a sharing process to increase both individual and common capacities of employees in order to make affairs more effective. (Yukl, 2002). This means adoption and voluntarily sharing of leadership by employees.

\subsection{Components of Shared Leadership}

Shared leadership is different from other leadership types with its distinctive components. These components enable shared leadership to be expressed as a single type of leadership. (Chen, 2007): 
- Focusing on shared activities: Revealing the leadership of employees through their voluntary participation to the activities, their acting in tasks and their influence on each other.

- Focusing on Student Success: What really matters is success. This motivates all employees to have a contribution to the outputs/achievements and to perform its leadership (Elmore, 2000; ref. Chen, 2007).

- Being able to recognize talents of employees: There exist common goal and cooperative work. With sharing leadership with employees' talents of whom are recognized, feeling as a leader and taking on responsibility of each employee becomes more meaningful (Gronn, 2002).

- Pushing the lines: Not limiting one's himself or herself with predetermined work streams. Bringing new idea sup by using previous studies (NCSL (National College for School Leadership, England), 2003).

- Focusing on interaction between leaders and their followers: At shared leadership there exists an interaction between leadership performer and his followers. This interaction means also follower's influence on leader. And this in turn means followers also perform leadership or contributes to common goal (Spillane, 2006).

\subsection{Shared Leadership at Education and Training Institutions}

Education and training groups which are among the most important ones of social organizations are the institutions which both influence society and is influenced by it. From this aspect, shared leadership has gained place at educational organizations. Staff within the organization working as specialist at distinct fields is within an interaction between both their fields and general operation of the society. Because of this interaction and complicated structure, common sense and making decisions in common have to be adopted rather than leadership of a single person (Hoy and Miskel, 2010). Hence, a structure which will make different leaderships at different departments or different fields possible should be formed (Beycioğlu and Aslan 2007).

Shared leadership in terms of educational organizations means being in struggle of the groups working in the organization (teacher, manager, other employees) for development of the organization in all fields (Jacops, 2010). As it is the case in many other fields, also within educational organizations it is impossible to expect just one leader to solve all the problems. Therefore, it is required that every employee within the organization should share the leadership in the organization in such a manner that he or she expresses his or her opinion, takes responsibility and contributes to common sense. Performing shared leadership within organization is based on sharing of duties and responsibilities at the highest point where conditions permit (Yener, 2014). Performing shared leadership within educational institutions means formation of structural organs in order to spread the leadership to a wide base; rewarding of proposals and Works of the employees which contribute to the organization and approval of innovation as a value within the organization. One of the most important dimensions of performing shared leadership at organizations is employees' trust in the organization. It is difficult for an 
employee who feels himself or herself within the organization to take responsibility or use the leadership initiative within the organization.

\subsection{Organizational Trust}

Organizational trust means that employees consider that the organization foe which they serve will protect employees' rights and will not act contrary to employees' interests (Gambetta, 1988). Organizational trust has been attracting scholars' interest in recent years. This interest is due to adopting shared leadership rather than classical leadership of modern organizations and their preference of horizontal structuring. It is foreseen that within organizations with horizontal structuring employees working in the organization will perform more actively and will take responsibility for the organization. In modern organizations, the trust of the employees in the organization leader and the organization is as important as the trust of leader in his/her employees in terms of the efficiency of the organization (Topaloğlu, 2010). Formation of organizational trust is a long term process. Throughout this process, employees should respect and welcome each other and have to behave in a compatible manner. Organization behavior is formed in a long term as a result of continuation of these behaviors. (Demircan and Ceylan, 2003). Organizational trust is mainly composed of three dimensions as trust in manager, trust in colleagues and trust in organization itself. Trust in the manager is possible when they share organization's utilities equally, when they are accessible in order to provide motivation of employees and when they designate significant goals (Mishra and Morrisey, 1990; Gürbüz, 2012). Employees should be clearly informed about issues they have to pay attention while working, they have to be provided some sort of freedom in their fields, and should be let use some sort of initiative (Serdar, 2019). Employees working in same place and for the same goal should trust each other. Employees' building a team is possible with just trusting each other. Organizations members who trust in their colleagues may succeed adopting the organization, loyalty to the organization and team dynamics (Topaloğlu 2010). Employees' trust in organization means their trust in culture, policies and operations of the society. Trust in organization may sometimes be confused with trust to manager. This is due to a belief that the manager represents the organization. Employees of organization should believe that the organization has a culture extending from past to future and independent from the manager and organization has a policy not changing depending on the manager and processes related to operation of the organization have a hardly changing characteristic (Tan and Tan, 2000).

Organizational trust is considered significant since it minimizes uncertainty and chaos within the organization; increases communication among each other and cooperation capacities (Günüşen, 2016; Yıldız, 2019). Values such as honesty, helpfulness, competence, trustworthiness and transparency are considered significant in educational organizations for obtaining success (Tschannen \& Hoy, 1998; Y1lmaz, 2006). Organizational trust contributes to change and development of school, gives teachers a hope for future, helps teachers understand each other better, increases efficiency and 
effectiveness of the business, makes teachers more open to change and provides thinking in order to be better (İsmayılov, 2019).

\subsection{Job Satisfaction}

Job satisfaction having been subject to scientific research since the beginning of 1900s has been studied by Elton Mayo within the scope of Hawthorne studies. In 1940s, by expressing that employees are different from machines, job satisfaction has been started to be studied as a way of getting more efficiency from employees (Güney, 2017; Eğinli, 2009; Taş and Önder, 2010). Job satisfaction is important for the employees who spend most of the day at workplace. Job satisfaction is described as a component of feelings held by employees against his or her work; (Locke, 1976), Mood of employee against his or her work under psychological and environmental conditions (Hoppock, 1935), suitability of rewards given to employees by employers when they finish the given work (Smith, 1977); or the main measure of competence (Başbekleyen, 2019; Demiray, 2018). Based on these explanations it may be stated that job satisfaction is fact which influences not only the employee, but also the organization and the manager.

Job satisfaction generally affects perspective of employee on life in a positive manner. Employees with a high job satisfaction have a better physical and psychological health, and less behavioral disorder. Moreover, job satisfaction also positively affects personal trust in the employee, harmony in the workplace, collaboration and cooperation, and reduces anxiety and tension in the employee. (Şakac1, 2019). The employee develops a negative attitude towards the organization when he/she notices that his expectations and the opportunities provided by the organization are different. This manner in turn affects job satisfaction negatively (Eğinli, 2009). Employees with high job satisfaction are generally satisfied with their work environments (Özgen and Yalçın, 2011). Hierarchical structure in the organization among subordinates and superiors operate functions well (Demiray, 2018). Samadov's (2006) study demonstrates that manager's attitudes and behaviors against employees' influence job satisfaction level of employees. Manager's gentle and helpful attitude, his admiration of employees and rewarding them when necessary increase job satisfaction level of employees.

\subsubsection{Factors Influencing Job Satisfaction}

Job satisfaction is not observed in the same way at every employee and organization. There are individual and organizational factors influencing job satisfaction (Tengilimoğlu, 2005). Individual factors may be specified as age, sex, marital status, seniority, status, education level, skill, performance, personality of employee. Organizational factors may be specified as wage and conferment, working conditions, feature of work, will for promotion and progress, employment security, management style, supervision, relations with colleagues and participation to decision making process (Akbulut, 2015). 


\section{Material and Methods}

In this part of the study explanations related to kind of the research, sample, data collection tolls and data analysis take place.

\subsection{Model of the Research}

In this study, a relational surveying model was used to determine the effect of shared leadership of educational organizations on teachers' job satisfaction and organizational trust, based on the perceptions of teachers. Relational surveying model is a scanning approach to determine whether two or more variables change together, if so, to determine the direction of the change. (Karasar, 2007). In this model there are many elements in the population. In order to reach a general judgment about this population, scanning is done throughout the whole population or on a sample group taken from the population.

\subsection{Population and Sample}

Target population of the study is composed of teachers working in State schools affiliated to Ministry of National Education and located in central districts of Malatya in 2019-2020 Academic Year. 5465 teachers working fort he mentioned institutions constitutes the population of the study. As a result of difficulties such as difficulty at reaching whole of the population, limited time and economic difficulties the research is conducted on a sample which is considered to be large enough to represent the population. Sample is defined as a subgroup which is large enough to represent universe (Çıng1, 1990). Since population is located in Central Malatya and general characteristic of the schools are like each other, schools included in the research have been selected random sampling method. At this study 512 teachers are reached. Data from teachers who have inadequately or incorrectly filled their questionnaires are not processed and research is based on 476 questionnaires.

Frequency and percentage distribution indicating demographic characteristics of the sample (sex, age, marital status, education level, seniority and branch) is as indicated in Table 1.

Table 1: Demographic Characteristics of the Participants

\begin{tabular}{|c|c|c|c|c|c|c|c|}
\hline Variables & Sub dimensions & $\mathrm{f}$ & $\%$ & Variables & Sub dimensions & $\mathrm{f}$ & $\%$ \\
\hline \multirow{2}{*}{ Sex } & Woman & 224 & 47,1 & \multirow{2}{*}{ Education } & Undergrad & 428 & 89,9 \\
\hline & Man & 252 & 52,9 & & Grad & 48 & 10,1 \\
\hline \multirow{5}{*}{ Age } & $20-29$ & 44 & 9,2 & \multirow{5}{*}{ Seniority } & $0-5$ years & 24 & 5 \\
\hline & $30-35$ & 72 & 15,1 & & $6-10$ years & 52 & 10,9 \\
\hline & $36-40$ & 152 & 31,9 & & $11-15$ years & 124 & 26,1 \\
\hline & $41-49$ & 136 & 28,6 & & $16-20$ years & 136 & 28,6 \\
\hline & 50 and over & 72 & 15,1 & & 20 and over years & 140 & 29,4 \\
\hline \multirow{2}{*}{ Marital Status } & Married & 416 & 87,4 & \multirow{2}{*}{ Branch } & Form Tutor & 188 & 39,5 \\
\hline & Single & 60 & 12,6 & & Branch Teacher & 288 & 60,5 \\
\hline
\end{tabular}




\subsection{Data Collection Tools}

Form used in the research in order to collect data consists of two sections. In the first section, questions related to demographic characteristics of the participants take place. In the second section shared leadership, job satisfaction and organizational trust scales take place.

\subsubsection{Personal Information Sheet}

This form constitutes of six questions intended to determine sex, age, marital status, education level, seniority and branches of teachers taking place in the sample.

\subsubsection{Shared Leadership Scale}

This scale has been developed by Wood (2005) and adapted to Turkish by Bostanc1 (2012). Scale is composed of 18 clauses and 4 sub dimensions. These sub dimensions are; fulfillment of tasks commonly (9 clauses), mutual skill development (2 clauses), decentralized interaction (4 clauses) and emotional support (3 clauses). 12. 14. and 15. clauses belonging to decentralized interaction are coded reversely. At reliability analysis of this scale held by Bostanc1, Cronbach alpha $(\alpha)$ value has been found as .91. Cronbach alpha value found for this research is .82. For all clauses of Shared Leadership Scale a 5 point likert type is used as 1- "Absolutely Wrong", 2- "Generally Wrong", 3- "May be both right or wrong", 4- "Generally right", 5- "Absolutely Right". While findings of the research analyzed arithmetic mean intervals have been evaluated as: 1.00-1.80: "Absolutely Wrong", 1.81-2.60: "Generally Wrong", 2.61-3.40: "May be both right and wrong", 3.41-4.20: “Generally Right", 4.21-5.00: "Absolutely right".

\subsubsection{Job Satisfaction Scale}

Job satisfaction Scale has been developed by Hackman and Oldham (1975) and adapted to Turkish by Silah (2003). Scale which has been made applicable to teachers by Taşdan (2008) has a five point graduation type and answered between the arrival of 1- Never Satisfied and 5- Strongly Satisfied. While findings of the research analyzed arithmetic mean intervals have been evaluated as 1.00-1.80: "Never Satisfied", 1.81- 2.60: "Not Fully Satisfied", 2.61-3.40: "Moderately Satisfied", 3.41-4.20: "Much Satisfied", 4.21- 5.00: "Absolutely Satisfied". The scale is composed of 14 issues. At reliability analysis of the scale by (2002) Cronbach alfa $(\alpha)$ value has been found as 0,95 . Cronbach alpha value found for this research is 0,89 .

\subsubsection{Organizational Trust Scale}

The scale has been developed by Yilmaz (2006) and has 22 issues and these issues are composed of three dimensions as trust in colleagues, managers and partners. 8 issues are related with "trust in colleagues" (issues 2, 6, 7, 8, 13, 16, 21, 22), 7 issues are related with "trust in managers" (issues 1, 5, 9, 10, 12, 15 and 17) and 7 issues are related to "trust in partners" (issues $3,4,11,14,18,19,20)$. The scale has a five point graduation type and includes the answers: 1- Never 2- Rarely 3- Sometimes 4- Mostly 5- Always. While 
findings of the research analyzed arithmetic mean intervals have been evaluated as; 1.00 1.80: "Never", 1.81- 2.60: "Rarely", 2.61-3.40: "Sometimes", 3.41-4.20: "Mostly", 4.21- 5.00: "Always". At reliability analysis of this scale held by Yilmaz (2006), Cronbach alpha $(\alpha)$ value has been found as .92. Cronbach alpha value found for this research is .90 .

\subsection{Data Analysis}

Data gathered from field application of the research have been analyzed through SPSS 21.0 program.

1) First, frequency and percentage calculations of answers to demographic variables taking place at individual information sheet (sex, age, marital status, education level, seniority and branch) have been carried out.

2) Then, means related to Shared Leadership, Job Satisfaction and Organizational Trust have been calculated. These means later have been used at determination of perceptions of the teachers on shared leadership, job satisfaction and organizational trust at their schools.

3) At the next stage of the analysis, t-test has been applied in order to analyze whether perceptions of the teachers on shared leadership, job satisfaction and organizational trust at their schools differ in regards to demographic variables.

4) At the next stage, a correlation analysis has been held in order to determine whether a relationship exists among shared leadership, job satisfaction and organizational trust.

5) As the last analysis, a regression analysis has been held in order to determine whether or not shared leadership predicts job satisfaction and organizational trust of the teachers.

\section{Results}

Findings acquired as a result of data analysis takes place in an order indicated in Figure 1.

\begin{tabular}{|c|c|c|c|}
\hline $\begin{array}{l}\text { 1. Means and Standard } \\
\text { deviations belonging } \\
\text { to shared leadership, } \\
\text { job satisfaction and } \\
\text { organizational trust. }\end{array}$ & $\begin{array}{l}\text { 2. Significance level of } \\
\text { shared leadership, job } \\
\text { satisfaction and } \\
\text { organizational trust in } \\
\text { regard to demographic } \\
\text { variables }\end{array}$ & $\begin{array}{l}\text { 3. Correlation values of } \\
\text { teachers' perception on } \\
\text { shared leadership, } \\
\text { organizational trust } \\
\text { levels and job } \\
\text { satisfaction levels. }\end{array}$ & $\begin{array}{l}\text { 4. Multiple } \\
\text { regression analysis } \\
\text { related to prediction } \\
\text { of the teachers' job } \\
\text { satisfaction by } \\
\text { perceived shared } \\
\text { leadership level }\end{array}$ \\
\hline
\end{tabular}

Figure 1: Findings Flowchart

Data related to present levels of shared values, organizational trust and job satisfaction at schools are demonstrated at Table 2. 
RELATION AMONG MANAGERS, TEACHERS AND SCHOOLS AT STATE SCHOOLS IN TURKEY: SHARED LEADERSHIP, JOB SATISFACTION, ORGANIZATIONAL TRUST

Table 2: Shared leadership, job satisfaction and organizational trust levels

\begin{tabular}{lccccc}
\hline & $\mathbf{N}$ & $\begin{array}{c}\text { Minimum } \\
\text { value }\end{array}$ & $\begin{array}{c}\text { Maximum } \\
\text { value }\end{array}$ & $\overline{\mathbf{x}}$ & SD \\
\hline Shared leadership & 476 & 2,70 & 4,86 & 3,6372 &, 38785 \\
\hline Job Satisfaction & 476 & 2,07 & 4,98 & 3,6351 &, 57336 \\
\hline Organizational Trust & 476 & 2,79 & 4,68 & 3,9254 &, 39852 \\
\hline
\end{tabular}

According to Table 2, mean of shared leadership at the schools is 3,63. This value means that leadership is generally shared at schools. This finding is evaluated as "Generally

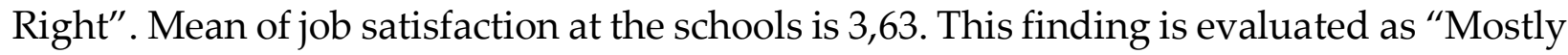
satisfied". This value means that teachers are generally satisfied with their job. Organizational trust mean referring to trust felt by teachers against their schools is 3,92. This means that teachers mostly trust in their schools.

At this research it is examined whether shared leadership, teachers' job satisfaction and organizational trust levels differ significantly in reference to demographic variables. Findings gathered from this examination are illustrated at Table 3.

Table 3: Significance status of shared leadership, job satisfaction and organizational trust level by gender, marital status, educational status and branch difference.

\begin{tabular}{|c|c|c|c|c|c|c|}
\hline & Sex & $\mathbf{N}$ & $\bar{x}$ & SD & $\mathbf{t}$ & $\mathbf{p}$ \\
\hline \multirow[t]{8}{*}{ Shared Leadership } & Woman & 224 & 3,6809 & ,38117 & \multirow{2}{*}{2,330} & \multirow{2}{*}{, $020^{*}$} \\
\hline & Man & 252 & 3,5983 & ,39034 & & \\
\hline & Married & 416 & 3,6493 & ,39680 & \multirow{2}{*}{1,798} & \multirow{2}{*}{,073 } \\
\hline & Single & 60 & 3,5532 & ,30880 & & \\
\hline & Graduate & 428 & 3,6501 & ,39019 & \multirow{2}{*}{658} & \multirow{2}{*}{, 531} \\
\hline & Undergraduate & 48 & 3,5226 & 34948 & & \\
\hline & Form Tutor & 188 & 3,6760 & 40242 & \multirow{2}{*}{1,766} & \multirow{2}{*}{,078 } \\
\hline & Branch Teach & 288 & 3,6119 & ,37659 & & \\
\hline \multirow[t]{8}{*}{ Job satisfaction } & Woman & 224 & 3,7462 & ,49375 & \multirow{2}{*}{4,051} & \multirow{2}{*}{, $000^{*}$} \\
\hline & Man & 252 & 3,5363 & ,62026 & & \\
\hline & Married & 416 & 3,6284 & ,57728 & \multirow{2}{*}{,- 663} & \multirow{2}{*}{, 508} \\
\hline & Single & 60 & 3,6810 & ,54786 & & \\
\hline & Graduate & 428 & 3,6509 & ,57254 & \multirow{2}{*}{1,801} & \multirow{2}{*}{,072 } \\
\hline & Undergraduate & 48 & 3,4940 & ,56720 & & \\
\hline & Form Tutor & 188 & 3,5562 & ,59168 & \multirow{2}{*}{661} & \multirow{2}{*}{, 515} \\
\hline & Branch Teach & 288 & 3,6865 & ,55611 & & \\
\hline \multirow[t]{8}{*}{ Organizational Trust } & Woman & 224 & 3,9342 & ,34587 & \multirow{2}{*}{456} & \multirow{2}{*}{649} \\
\hline & Man & 252 & 3,9175 & ,44062 & & \\
\hline & Married & 416 & 3,9192 & ,41716 & \multirow{2}{*}{,- 891} & \multirow{2}{*}{,373 } \\
\hline & Single & 60 & 3,9683 & ,22904 & & \\
\hline & Graduate & 428 & 3,9190 & ,39807 & \multirow{2}{*}{$-1,041$} & \multirow{2}{*}{ 298 } \\
\hline & Undergraduate & 48 & 3,9821 & ,40222 & & \\
\hline & Form Tutor & 188 & 3,9295 & ,44921 & \multirow{2}{*}{,181 } & \multirow{2}{*}{857} \\
\hline & Branch Teach & 288 & 3,9227 & ,36243 & & \\
\hline
\end{tabular}

\footnotetext{
${ }^{*}=\mathrm{p}<0,05$
} 
When Table 3 is examined it will be noticed that at the level of shared leadership at primary schools there is a significant difference between men and women. $[\mathrm{t}(474)=2,330$, $\mathrm{p}<0,5]$. When arithmetical mean of women and men considered, women's shared leadership scores $(\bar{x}=3,6809)$ are higher than men's $(\bar{x}=3,5983)$. According to this data, women consider shared leadership at schools significantly higher. Shared leadership level at the schools does not differ significantly in respect to marital status, education level and branch. While examining whether job satisfaction of teachers significantly differ in respect to sex, marital status, education level and branch, it has been noticed that there is a significant difference between men and women. [t(474)=4,051, $\mathrm{p}<0,5]$. This significant difference may also be understood in respect to arithmetic means of women $(\bar{x}=3,7462)$ and men $(\bar{x}=3,5363)$. In the light of this finding, it can be stated that job satisfaction of women are significantly higher than men's. Job satisfaction level of teachers does not differ significantly in respect to marital status, education level and branch. It is also determined that organizational trust level of teaches has not differed significantly in respect to marital status, education level and branch $(p>0,5)$.

Shared leadership, job satisfaction and organizational trust at the primary schools have been examined in respect to variables of sex and seniority and findings are demonstrated at Table 4.

Table 4 indicates that there isn't a significant difference among 20-29 years old group and other groups $(p>0,5)$. Three groups consisting of 30-35 years old group $(p=, 033), 36-40$ years old group $(p=, 039)$ and $41-49$ years group $(p=, 039)$ significantly differ from 50 and over years old group. If the correspondence of this difference in respect to means, it is noticed that the mean of 50 and over years old group is $(\bar{x}=3,7890)$ is significantly higher than of $30-35$ years old group is $(\bar{x}=3,5806)$, of $36-40$ years old group is $(\bar{x}=3,6137)$ and $41-49$ years old group $(\bar{x}=3,6101)$. It is determined no difference among seniority groups in respect to shared leadership $(p>0,5)$.

When age groups are analyzed in respect to job satisfaction, it is noticed that there is a significant difference between 20 and over years old group and other groups i.e. 2029 years old group, 30-35 years old group and 35-40 years old group. This difference is significantly high at 50 and over years old group. There is no significant difference between $41-49$ years old group and 50 and over years old group. This significance is more explicit when arithmetic means of the groups are taken into account. When job satisfaction is examined in respect to seniority groups, it is noticed that there is a significant difference between $0-5$ years seniority group and 20 an over years seniority group. ( $p=033$ ). This difference also exists also between arithmetic mean of $0-5$ years seniority group in respect to job satisfaction $(\bar{x}=3,2857)$ and arithmetic mean of the group consisting of teachers having seniority of 20 and over years $(\bar{x}=3,7418)$. It isn't determined any significance among seniority groups in respect to job satisfaction. ( $p>0,5)$. 
RELATION AMONG MANAGERS, TEACHERS AND SCHOOLS AT STATE SCHOOLS IN TURKEY: SHARED LEADERSHIP, JOB SATISFACTION, ORGANIZATIONAL TRUST

Table 4: $X$ and $p$ values table on Multiple Comparison Method of shared leadership, job satisfaction and organizational trust in respect to age and seniority variables

\begin{tabular}{|c|c|c|c|c|c|c|c|}
\hline & & $\bar{x}$ & $\begin{array}{l}20-29 \\
\text { years }\end{array}$ & $\begin{array}{l}30-35 \\
\text { years }\end{array}$ & $\begin{array}{l}36-40 \\
\text { years }\end{array}$ & $\begin{array}{l}41-49 \\
\text { years }\end{array}$ & $\begin{array}{c}50 \text { and } \\
\text { over years }\end{array}$ \\
\hline \multirow{11}{*}{ 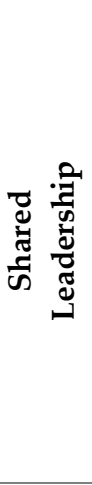 } & 20-29 years & 3,6465 & & ,938 & ,993 &, 990 &, 440 \\
\hline & $30-35$ years & 3,5806 & ,938 & & ,985 & ,991 & ,033* \\
\hline & $36-40$ years & 3,6137 & ,993 & ,985 & & 1,000 & ,039* \\
\hline & $41-49$ years & 3,6101 & ,990 & ,991 & 1,000 & & ,039* \\
\hline & 50 and over years & 3,7890 & 440 & ,033* & ,039* &, $038^{*}$ & \\
\hline & & $\bar{x}$ & $0-5$ Years & 6-10 Years & 11-15 Years & 16-20 Years & 20 and over years \\
\hline & $0-5$ Years & 3,5764 & & ,995 & 1,000 & ,984 & ,613 \\
\hline & 6-10 Years & 3,6202 & ,995 & & ,975 & 1,000 & 674 \\
\hline & 11-15 Years & 3,5759 & 1,000 & ,975 & & ,871 & ,072 \\
\hline & 16-20 Years & 3,6293 & ,984 & 1,000 & ,871 & & ,482 \\
\hline & 20 and over years & 3,7159 & ,613 & ,674 & ,072 & ,482 & \\
\hline \multirow{11}{*}{ 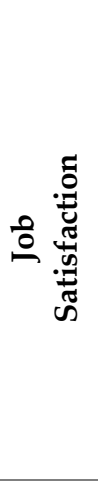 } & 20-29 years & 3,5740 & & 870 & ,373 & ,088 &, $024^{*}$ \\
\hline & $30-35$ years & 3,5894 & ,870 & & ,709 & ,585 &, $037^{*}$ \\
\hline & $36-40$ years & 3,6391 & ,373 & ,709 & & ,456 &, $042^{*}$ \\
\hline & 41-49 years & 3,7659 & ,088 & ,585 & ,456 & & ,652 \\
\hline & 50 and over years & 3,7937 &, $024^{*}$ &, $037^{*}$ &, $042^{*}$ & 652 & \\
\hline & & $\bar{x}$ & 0-5 Years & 6-10 Years & 11-15 Years & 16-20 Years & 20 and over years \\
\hline & $0-5$ Years & 3,2857 & & ,147 & ,055 & ,092 &, $033^{*}$ \\
\hline & 6-10 Years & 3,6143 & ,147 & & ,753 & ,952 & ,996 \\
\hline & 11-15 Years & 3,6728 & ,055 & 753 & & ,996 & ,888 \\
\hline & 16-20 Years & 3,6429 & ,092 & ,952 & ,996 & & ,970 \\
\hline & 20 and over years & 3,7418 & ,033* & ,996 & ,888 & ,970 & \\
\hline \multirow{11}{*}{ 胥 } & 20-29 years & 4,0119 & & ,986 & ,218 & ,239 & ,717 \\
\hline & $30-35$ years & 3,9679 & ,986 & & ,362 & ,396 & ,242 \\
\hline & $36-40$ years & 3,8523 & ,218 & ,362 & & 1,000 &, $000 *$ \\
\hline & 41-49 years & 3,8538 & ,239 & ,396 & 1,000 & &, $000^{*}$ \\
\hline & 50 and over years & 4,1194 & ,717 & ,242 &, $000^{*}$ &, $000^{*}$ & \\
\hline & & $\bar{x}$ & $0-5$ Years & 6-10 Years & 11-15 Years & 16-20 Years & 20 and over years \\
\hline & $0-5$ Years & 3,8581 & &, 254 & ,999 & 1,000 &, 642 \\
\hline & 6-10 Years & 4,0820 & ,254 & & ,053 &, $008^{*}$ & ,763 \\
\hline & 11-15 Years & 3,8834 & ,999 & ,053 & &, 954 & ,253 \\
\hline & $16-20$ Years & 3,8435 & 1,000 &, $008^{*}$ & ,954 & &, $036^{*}$ \\
\hline & 20 and over years & 3,9954 & ,642 & ,763 & 253 &, $036^{*}$ & \\
\hline
\end{tabular}

${ }^{*}=\mathrm{p}<0,05$

Analysis related to determining whether there is a significant difference among participants in respect to organizational trust indicates that 20-29 years old group and 3035 years old group significantly differ from other groups $(p>0,5)$. In addition, it is determined that there aren't significant differences between the groups of 36-40 years old group ( $p=, 039)$ and $41-49$ years old group $(p=, 039) 50$ and over years old group. When the correspondence of this difference at the means is examined, it is clearly noticed that mean of 50 and over years old group $(\bar{x}=4,119)$ is significantly higher than the groups of $36-40$ years old group $(\bar{x}=3,852)$ and $41-49$ years old group $(\bar{x}=3,853)$. The analysis aiming at determining whether difference at organizational trust points is significant indicates that the group differs significantly from the groups $(p=, 008)$ and 20 and over years of seniority $(p=, 036)$. Arithmetical mean related to organizational trust is $\bar{x}=4,082$ for the group having 
6-10 years of seniority; $\bar{x}=3,843$ for the group with seniority of $16-20$ years; and $\bar{x}=3,995$ for the group having 20 and over years of seniority. As it can be understood from these data, means of teachers having 6-10 years and 20 and over years seniority are significantly higher than the means of teachers having 16-20 years of seniority.

In order to determine whether it exists a significant relation between shared leadership at schools and job satisfaction and organizational trust, a correlation analysis has been made and findings of this analysis are demonstrated at Table 5.

Table 5: Correlation values for teachers' perceived shared leadership level and their organizational trust and job satisfaction level

\begin{tabular}{llcccc}
\hline \multirow{2}{*}{ Shared Leadership } & \multicolumn{3}{c}{ Shared Leadership } & Job Satisfaction & Organizational Trust \\
\cline { 2 - 5 } & $\mathrm{r}$ & 1 &, $364^{* *}$ &, $392^{* *}$ \\
\hline Job Satisfaction & $\mathrm{p}$ & &, 000 &, 600 \\
\hline Organizational Trust & $\mathrm{r}$ &, $364^{* *}$ & 1 &, 000 \\
\cline { 2 - 5 } & $\mathrm{p}$ &, 000 &, $647^{* *}$ & 1 \\
\hline & $\mathrm{r}$ &, $392^{* *}$ &, 000 & \\
\hline$* *$ & $\mathrm{p}$ &, 000 & &
\end{tabular}

${ }^{* *} \mathrm{p}<0,01$

Table 5 indicates that at the correlation analysis where relation between shared leadership at schools and job satisfaction and organizational trust, there is a positive, medium level and significant relationship between shared leadership and job satisfaction $(\mathrm{r}=, 364 ; \mathrm{p}=, 000)$; and shared leadership and organizational trust $(\mathrm{r}=, 392 ; \mathrm{p}=, 000)$. In a correlation analysis ,00-,29 then the relationship is low, if $r$ value is between , 30-,69 then the relationship is medium level; and if $r$ value is between,70-1,00, then the relation is high level (Saruhan and Özdemirci, 2013). After determining this significant relationship, in order to determine predictive situation of shared leadership on organizational trust and job satisfaction has been tried to be examined through regression analysis.

Table 6: Multiple regression analysis on prediction of job satisfaction and organizational trust of teachers by perceived shared leadership

\begin{tabular}{|c|c|c|c|c|c|c|c|c|c|}
\hline Variable Name & B & S. Error & $\beta$ & $\mathbf{t}$ & $\mathrm{p}$ & $\mathbf{R}^{2}$ & Adjusted R ${ }^{2}$ & Binary $\mathbf{r}$ & Partial r \\
\hline Constant & 1,714 & ,234 & & 7,311 &, $000^{*}$ & \multirow{2}{*}{ 156 } & \multirow{2}{*}{ 149 } & \multirow{2}{*}{,352 } & \multirow[b]{2}{*}{,346 } \\
\hline Shared Leadership &, 517 & 063 & 350, & 8,166 &, $000^{*}$ & & & & \\
\hline Constant & 2,482 & 163 & & 15,232 &, $000^{*}$ & \multirow{2}{*}{157} & \multirow{2}{*}{ 150 } & \multirow{2}{*}{,393 } & \multirow{2}{*}{ 392 } \\
\hline Shared Leadership & 408 &, 044 & 397, & 9,266 &, $000^{*}$ & & & & \\
\hline $\begin{array}{l}\text { a: Dependent Varial } \\
\text { b: Dependent Varia }\end{array}$ & $\begin{array}{l}\text { : Job S } \\
\text { Orga }\end{array}$ & $\begin{array}{l}\text { tisfaction } \\
\text { hizational }\end{array}$ & $\begin{array}{l}\mathrm{F}(1,47 \\
\text { Trust }\end{array}$ & $\begin{array}{l}5)=21,84 \\
(1,475)=\end{array}$ & $\begin{array}{l}0^{*}: p<0 \\
21,877\end{array}$ & $: 5<$ & & & \\
\hline
\end{tabular}

When parameters related to regression model are examined at Table 6 , it is seen that standardized regression coefficients are: $\beta=0.350 ; \mathrm{t}=8.166 ; \mathrm{p}<0.01$ (Shared Leadership). This means that shared leadership at school significantly predict teachers' job satisfaction in a positive manner. In view of this result, about $15 \%$ percent of job satisfaction of teachers is explained by shared leadership of the school $\left(\mathrm{R}^{2}=.149\right)$. 
When variables related to regression model held for predicting organizational trust are examined it is seen that standardized coefficients are: $\beta=0.397 ; \mathrm{t}=9.266 ; \mathrm{p}<0.01$ (Shared Leadership). This means that shared leadership at school significantly predict teachers' organizational trust in a positive manner. In view of this result, about $15 \%$ percent of job satisfaction of teachers is explained by shared leadership of the school $\left(\mathrm{R}^{2}=.150\right)$.

\section{Discussion and Conclusions}

Leadership, as in all areas of life, is a phenomenon that exists in the field of education due to natural and managerial processes. Different types of leadership have been analyzed throughout history of education. In this context, within this research findings regarding shared leadership, job satisfaction and organizational trust at schools in Turkey are discussed below. There are few studies concerning relationship and prediction of shared leadership with job satisfaction (Hulpia, Devos, Rosseel, 2009; Akyürek, 2016; Ağırdaş, 2014; Ulusoy, 2014). With this aspect, this research may be considered as an effort to meet this deficit.

Within this research, mainly four questions are tried to be answered. First question is "What are shared leadership, job satisfaction and organizational trust levels at primary schools?" When the results obtained in the study were examined, it is determined that the variables of shared leadership, job satisfaction and organizational trust were "generally / mostly high". Similar findings have been derived at distinct studies where these variables are examined. At the research held by Y1lmaz (2013) shared leadership level at the schools is "Mostly shared". Korkmaz (2011) also has analyzed shared leadership level at schools in Turkey and the result has been considered as "high" with a percentage of $76 \%$. When this level $(76 \%)$ is converted into this research's evaluation method (five point likert) the result is "mostly shared". At another research (Uslu and Beycioğlu, 2013) da it has been determined that "teachers' perception of the school's shared leadership level is high". Similar to these research, shared leadership has been pointed out as "mostly shared" at Sarıçiçek's (2014) research and "high" at researches held by Bakır (2013) and Çobanoğlu (2019). On the contrary, at a research held on shared leadership at secondary educational institutions in Turkey (Çınar, 2015), it is pointed out that shared leadership level is not high.

When findings of this research related to job satisfaction, it has been stated that job satisfaction is generally high. When some other researches in the literature are analyzed it will be noticed that findings are similar to this research's findings. At a research done by Gafa (2019), it has been determined that job satisfaction of teachers is at a high level. At another researches concerning job satisfaction of teachers, it has been determined that "both inner and outer satisfaction of teachers are high" (Dur, 2019), "general satisfaction level is high" (Kuzu, 2019) and "job satisfaction related to qualities of the profession is high" (Aydın, 2006). At a research done in Greece it has been determined that "teachers are satisfied with their profession and managements whereas they are not satisfied with income and 
opportunities related to future provided by their professions" (Koustelios, 2001). At a research done in Brazil, it has been stated that job satisfaction of teachers is not high (Lapo and Bueno, 2003). At a research done by Watson and others (1991) in Australia, it has been determined that job satisfaction among teachers is quite high.

At his research, organizational trust level of the teachers has been determined as "mostly trusting". In the literature there exist many researches corroborating findings of this research. It has been determined at a dissertation by Gülay (2018) that "organizational trust perception of teachers is well enough"; at research by Kahveci, (2015) it has been estimated that "organizational trust perception of teachers are high" at a research by Sarkaya (2019) performed by participation of teachers from primary, secondary and high schools "job satisfaction level of teachers is at a medium level". It is estimated at a research by Y1lmaz (2019) that "organizational trust level of teachers is high", at a research by Korkmaz (2019) on form teachers it has been determined that "form teachers mostly trust educational organization", at a research done by Kovanc1 (2019) organizational perception level of teachers has been stated as "mostly".

The second question which is tried to be answered within this research is that "Does shared leadership, job satisfaction and organizational trust perceptions of teachers significantly change in terms of demographic variables?" When shared leadership perception of teachers is analyzed in terms of demographic variables, it has been determined that shared leadership significantly differs in terms of sex and age variables. Thereafter, shared leadership perception of women is significantly higher than of men. Findings similar to findings of this research have been found out by different researches. At a research which is done by Grant (2011) at state schools in Northern Carolina, it has been stated that women have higher shared leadership perception than men. Similarly, at a research by Aydoğan (2018) it has been stated that shared leadership level of women is higher. In discordance with these researches, at a research done by Bak1r (2012), it has been determined that male teachers have higher shared leadership perception than female teachers. When shared leadership of teachers is analyzed in terms of age reliable, it has been determined that shared leadership perception of teachers over 50 is significantly higher than shared perception level of younger teachers. Similar to this research, at doctoral dissertation by Yener (2014) it has been determined that shared leadership perception level of teachers under 20 is significantly lower than of older teachers. Both researches indicate that the more the age of teachers the higher is their perception of shared leadership.

At this research it has been determined that job satisfaction level of teachers significantly differs in terms of demographic variables of sex, age and, seniority variables. Thereafter, job satisfaction level of female teachers, older teaches and teachers with higher seniorities are higher In some researches in literature (Fields and Blum, 1997; Çarıkçı, 2000; Demirel, 2006; Theoddossiou and Vasileiou, 2007; Özdöl, 2008; Adıgüzel et al. 2011) it has been determined that demographic variables does not create significant difference whereas in some researches (Akhtar, Hashmi \& Naqvi, 2010; Ololube, 2006; Sarpkaya, 2000) it has been determined that demographic variables create significant 
difference. Similar to this research, researches by Özdevecioğlu (2003), Long (2005) and Duman (2006) have stated that job satisfaction level of women are significantly higher than of men. When researches concerning effects of age on job satisfaction, it will be noticed that findings of these researches are similar with the findings of this research. According to Duman (2006), job satisfaction of teachers who are 40 or over is higher than of the younger teachers. Yilmaz (2019) states that teachers over 51 have higher levels than the youngers; and Gündoğdu (2013) indicates that younger teachers have less jobs satisfaction. Davis (1988) states that job satisfaction level of older employee increases because of experience they gain; and Glenn et al. (1977) state that older employees have higher job satisfaction levels than younger employees have. At this research it has also been determined that employees with higher seniorities have higher job satisfaction. In the literature Duman (2006) has similarly indicated that teachers having 11 years or more seniority have higher level of job satisfaction than teachers having less seniority. According to Y1lmaz (2019) teachers with seniority of 21 or more years; and according to Gündoğdu (2013) teachers having a seniority of 21-25 years have higher levels of job satisfaction than teachers having less seniority. Hunt and Saul (1975) assert that as the seniority of employee increases their expectations decrease and thus their level of job satisfaction increases.

At this research, it has been found out that organizational trust of teachers significantly differs in terms of age and seniority. Organizational trust scores of teachers over 50 are significantly higher than of teachers who are 35-50 years old. In respect to seniority, organizational trust levels of teachers having a seniority of more than 20 years are higher than teachers having 6-10 and 16-20 years of seniority. Organizational trust of both older teaches and teachers with high seniority are significantly higher than younger teachers Another finding derived from these findings is that organizational trust level of teachers who have started to work relatively new (20-35 years old and 0-5 years seniority) is neither significantly high nor low. At other researches in literature on organizational trust findings similar to the findings of this research have been acquired. As consequence of Tukey multiple comparisons test done by Saruhan (2019) it has been found out at there is a significant difference between 22-27 years old group and 40-45 years old group. The teachers who are over 46 have the highest level of organizational trust. At Ayduğ's (2014) research teachers having the lowest level of organizational trust are the teachers who are 21-30 years old. At a research done by Kacabaş and Kartal (2016) it is stated that older teachers have higher levels of organizational trust than the younger teachers. When this research and other researches in the literature are compared, again similar findings have been found out. At a research done by Saruhan (2019), it has been stated that there is a significant difference between teachers having 0-5 years' seniority and the teachers having 16 years and over seniority in terms of organizational trust. At another research, it has been stated that teachers having the highest level of organizational trust are the ones who have 21 or more years of seniority; and the teachers having the lowest level of organizational trust are the ones who have 9 to 12 years of seniority (Ayduğ, 2014). Özer et al. (2006) have considered that the organizational trust level of teachers' group who 
have the highest seniority is more positive than the other groups of teachers. At a research done by Bilgiç and Gümüşeli (2012), it is stated that organizational trust level of teachers having 20 or more years of seniority is significantly higher than organizational trust level of teachers having 1 to 5 years of seniority.

The third question answer of which is tried to be found is that: "Are the shared leadership perceptions of the teachers related with their job satisfaction and organizational trust?" At the correlation analysis made in order to determine shared leadership's correlation with job satisfaction and organizational trust, it has been established that shared leadership has a positive, significant and moderate correlation with both of the variables. At a research done by Hulpia, Devos and Rosseel (2009) it has been stated that at teachers there exists a positive correlation between shared leadership perception and job satisfaction. At the research done by Ağırdaş (2014) where correlation between shared leadership and job satisfaction at teachers working for state high schools is analyzed, it has been stated that there is a significant, high and positive correlation between shared leadership perception of participants and their level of job satisfaction. At the research done by Ulusoy (2014) it has been stated that there is a positive and significant correlation between shared leadership behaviors enacted at schools and job satisfaction of the teachers. It is determined that correlation between shared leadership roles of the managers and job satisfaction of the teachers is positive, moderate and meaningful. Positive, significant and moderate correlation which has been found through this research has also been found at many other researches in the literature. At a research done by Yllmaz (2014) it has been found out that there is a positive and significant correlation between shared leadership and organizational trust. Çiçek (2018) similarly has determined a positive and significant correlation between shared leadership and organizational trust. According to correlation analysis done within the research done by Ray (2019) it has been determined that there is a positive, moderate and significant correlation between teachers' perception about their schools' shared leadership practices and the teachers' organizational trust levels.

The fourth question which is tried to be answered through this research is that: "Does shared leadership at primary schools predict job satisfaction and organizational trust of teachers?" In compliance with findings of this research, shared leadership at primary schools predict both job satisfaction and organizational trusts of the teachers. Additionally, another finding of this research is that about 15\% percent of job satisfaction and organizational trust of teachers is predicted by shared leadership. Although there is little research done directly on shared leadership's predicting of organizational trust and job satisfaction, still there are some findings similar to findings of this research. In the literature shared leadership is studied under the names as distributed leadership, distributing leadership, sharing leadership whose definitions and contents are almost same with the term shared leadership. Within these researches, regression analysis which has been done by Ray (2019) it has been found out that shared leadership perception of the teachers significantly predicts their trust against their organizations. The finding mentioned and finding of this research are the same. At the research performed by Kim 
(2019) it is stated that shared leadership has positive effect on organizational trust; and it is also stated that shared leadership predicts organizational trust and in turn organizational trust predicts job satisfaction in a positive manner. Findings of the mentioned research and this research are similar. Another research which states that shared leadership has positive effect on organizational trust has been performed by (2019). It exists many researches similar to this research which aims at predicting job satisfaction of shared leadership. At the research held by Ulusoy (2014) it has been indicated that shared leadership at schools predicts job satisfaction significantly. Hulpia, Devos and Rosseel (2009) at their research have stated that some constituents of leadership (teacher leadership) directly effects job satisfaction whereas some other components (participation to decisions, participation of supervision, support) effects indirectly. Another research at which it is mentioned that shared leadership has got positive effects on job satisfaction has been performed by Wood and Fields (2007).

\section{Recommendations}

At this research, effects of shared leadership on teachers are examined. Especially limited with its effects on teachers' job satisfaction and organizational trust. Researchers at the field may analyze effects of shared leadership on managers, organizations, students' parents and students or they may analyze different aspects of shared leadership's effects on teachers. Moreover, this research is limited with primary schools in Malatya and 20192020 Academic year. Different researches may be held and tested at other stages of education, at different times and different locations.

For increasing teachers' job satisfaction and organizational trust it is important to form a school based on sharing, support efforts of teachers, integrate them to decision making processes; (Hulpia, Devos and Rosseel, 2009), to ensure effective participation of teachers to solution process of the problem and to the whole of the transmission and development efforts at the school (Yener, 2014). In light of findings of this research, in order to increase job satisfaction and organizational trust of teachers, they have to be included in decision making processes in an active manner. Motivating formal processes should be formed in order to prepare and perform projects which help to organizations and psychological states of teachers. It is proposed that leadership, tasks and responsibilities should be shared with teachers who are disposed to take the lead.

\section{About the Author}

Necati Çobanoğlu received Classroom teacher license (1999) from Süleyman Demirel University and master's degree (2013) at Zirve University. He completed his Ph.D. in Educational Administration at Gaziantep University in 2019. His doctoral thesis was a positive psychological capital study with shared leadership. Between the years 1999-2016 the Ministry of Education teachers in Turkey (11 years) and director (6 years) worked as. Between 2016-2020, he held different positions related to education management in 
Malatya Metropolitan Municipality. He still works in this institution. He continues his scientific studies (books, articles, papers etc.) in the field of education management.

\section{References}

Adıgüzel, Z., Karadağ, M. ve Ünsal, Y., 2011. Fen ve teknoloji öğretmenlerinin iş tatmin düzeylerinin bazı değişkenlere göre incelenmesi. Batı Anadolu Eğitim Bilimleri Dergisi, 2(4), 49-74. http://webb.deu.edu.tr/baed/giris/baed/4 3.pdf

Ağırdaş, Y., 2014. Resmi liselerde dağıtımcı liderlik ile iş doyumu arasındaki ilişkinin öğretmen görüşlerine dayalı olarak incelenmesi (Çorum ili örneği). Yayınlanmamış yüksek lisans tezi. Okan Üniversitesi Sosyal Bilimler Enstitüsü. https://tez.yok.gov.tr/UlusalTezMerkezi/giris.jsp

Ağıroğlu Bakır, A. ve Aslan, M., 2014. Paylaşılan liderliğin öğretmenlerin örgütsel bağlılığ1 üzerindeki Etkisi, e-International Journal of Educational Research, 5(3), 5671. https://doi.org/10.19160/e-ijer.38888

Akbulut, B., 2015. Ortaöğretim kurumlarında görev yapan öğretmenlerin örgütsel imaj algıları ile iş doyumu düzeyleri arasındaki ilişki. Yayınlanmamış doktora tezi. Hacettepe Üniversitesi Eğitim Bilimler https://tez.yok.gov.tr/UlusalTezMerkezi/giris.jsp

Akhtar, S. N., Hashmi, M. A. \& Naqvi, S. I. H., 2010. A comparative study of job satisfaction in public and private school teachers at secondary level. Procedia Social and Behavioral Sciences, 2(2), 4222-4228. https://doi.org/10.1016/j.sbspro.2010.03.668 Akyürek, M. İ., 2016. İlkokul müdürlerinin dağıtılmış liderlik özellikleri ile öğretmenlerin iş doyumu algıları arasındaki ilişki (Ankara ili örneği). Yayımlanmamış yüksek lisans tezi, Gazi Üniversitesi Eğitim Bilimleri Enstitüsü. https://tez.yok.gov.tr/UlusalTezMerkezi/giris.jsp

Ali, H. M., \& Yangaiya, S. A., 2015. Investigating the influence of distributed leadership on school effectiveness: a mediating role of teachers' commitment. Journal of Educational and Social Research, 5(1), 163-174. https://doi.org/10.5901/jesr.2015.v5n1s1p163

Aslan, M. ve Ağıroğlu Bakır, A., 2015. Okullarda paylaşılan liderlik ve örgütsel bağlılık etkileşimi: nitel bir çalışma. Electronic International Journal of Education, Arts, and Science. 1 (2), 1-30 http://www.eijeas.com/index.php/EIJEAS/article/view/45

Aydın, D., 2006. Eğitim kurumu çalışanlarında iş doyumu. Yayımlanmamış yüksek lisans tezi, Marmara Üniversitesi Sosyal Bilimler Enstitüsü. https://tez.yok.gov.tr/UlusalTezMerkezi/giris.jsp

Aydoğan, H., 2018. Özel eğitim okullarında ve rehabilitasyon merkezlerinde çalışan yönetici ve öğretmenlerin paylaşılan liderlik algısı ile örgütsel bağlılık düzeyleri. Yayımlanmamış yüksek lisans tezi, Uşak Üniversitesi Sosyal Bilimler Enstitüsü. https://tez.yok.gov.tr/UlusalTezMerkezi/giris.jsp 
Ayduğ, D., 2014. İlkokulların örgüt sağlığı ile öğretmenlerin örgütsel güven düzeyleri arasındaki ilişkilerin incelenmesi. Yayımlanmamış yüksek lisans tezi, Anadolu Üniversitesi Eğitim Bilimleri Enstitüsü. https://tez.yok.gov.tr/UlusalTezMerkezi/giris.jsp

Bakır, A. A., 2013. Öğretmenlerin paylaşılan liderlik ve örgütsel bağlllık algıları arasındaki ilişkinin analizi. Yayımlanmamış doktora tezi, İnönü Üniversitesi Eğitim Bilimler Enstitüsü. https://tez.yok.gov.tr/UlusalTezMerkezi/giris.jsp

Bakır, A. A., 2012. Öğretmelerin paylaşılan liderlik ve örgütsel bağlılıkları arasındaki ilişkinin analizi. İnönü Üniversitesi Yayınlanmamış Doktora tezi. https://tez.yok.gov.tr/UlusalTezMerkezi/giris.jsp

Baloğlu, N., 2011. Dağıtımcı liderlik uygulamaları: Eklektik bir tasarım çalışması, Ahievran Üniversitesi Kırşehir Eğitim Fakültesi Dergisi, 12(4), 163-181.

Başbekleyen, M. A., 2019. Okul yöneticilerinin dönüşümsel, etkileşimsel liderlik davranışları ile iş doyumu arasındaki ilişki. Yayınlanmamış yüksek lisans tezi. Marmara Üniversitesi - İstanbul Sabahattin Zaim Üniversitesi. https://tez.yok.gov.tr/UlusalTezMerkezi/giris.jsp

Beycioğlu, K., 2009. İlköğretim okullarındaki öğretmenlerin sergiledikleri liderlik rollerine ilişkin bir değerlendirme (Hatay ili örneği). Yayımlanmamış doktora tezi, İnönü Üniversitesi Sosyal Bilimler Enstitüsü. https://tez.yok.gov.tr/UlusalTezMerkezi/giris.jsp

Beycioğlu, K. ve Aslan, M., 2007. The need for organizational innovations in public elementary schools. International Journal of Educational Reform, 16(1), 27-37. https://doi.org/10.1177\%2F105678790701600103

Bilgiç, Ö. ve Gümüşeli, A. İ., 2012. Research on teachers' level of trust to the colleagues, the students and the parents. Procedia-Social and Behavioral Sciences, 46, $5470-5474$. https://doi.org/10.1016/j.sbspro.2012.06.459

Bennett, N., Wise, C., Woods, P. A. \& Harvey, J. A., 2003. Distributed Leadership: A Review of Literature. National College for School Leadership. Full Report. oro.open.ac.uk.

Bolden, R., Petrov, G. \& Gosling, J., 2009. Distributed leadership in higher education, Educational Management Administration and Leadership, 37(2), 257-277. https://doi.org/10.1177\%2F1741143208100301

Bostancı, A. B., 2012. Paylaşılan liderlik algısı ölçeği'nin türkçe uyarlaması, International Journal of Human Sciences, 9(2), 1619-1631.

Chen, Y. H., 2007. Principals' distributed leadership behaviors and their impact on student achievement in selected elementary schools in Texas a dissertation. Texas: A\&M University.

Çarıkçı, İ. H., 2000. Çalışanların iş tatminlerini etkileyen kişisel özellikler-süpermarket çalınanları üzerinde bir araştırma. Süleyman Demirel Üniversitesi İktisadi ve İdari Bilimler Fakültesi Dergisi, 5(2), 155-168.

Çınar, A., 2015. Ortaöğretim kurumlarında paylaşılan liderlik algısı: Gerçek mi? Olabilir mi? Hayal mi? Yayımlanmamış yüksek lisans tezi, Erciyes Üniversitesi Eğitim Bilimleri Enstitüsü. https://tez.yok.gov.tr/UlusalTezMerkezi/giris.jsp 
Çiçek, E., 2018. Eğitim kurumlarında dağıtımcı liderlik ve örgütsel güven arasındaki ilişki: Kayseri il merkezi örneği. Yayımlanmamış yüksek lisans tezi, Nevşehir Hacıbektaş Veli Üniversitesi Sosyal Bilimler Enstitüsü. https://tez.yok.gov.tr/UlusalTezMerkezi/giris.jsp

Çobanoğlu. N., 2019. İlköğretim okullarındaki paylaşılan liderlik ve öğretmenlerin pozitif psikolojik sermayeleri üzerine bir araştırma. Yayınlanmamış doktora tezi. Gaziantep Üniversitesi Eğitim Bilimleri Enstitüsü. https:/tez.yok.gov.tr/UlusalTezMerkezi/giris.jsp

Davis, K., 1988. İşletmede insan davranışı. (Çev: K. Tosun vd.). İstanbul: İ.Ü. İşletme Fakültesi Yayınları.

Davis, M. W., 2009. Distributed leadership and school performance Unpublished doctoral dissertation. The graduate school of education and human development of george, USA: Washington University.

Demiray, S., 2018. Psikolojik güçlendirme ile iş doyumu arasındaki ilişki. Yayınlanmamış yüksek lisans tezi. Pamukkale Üniversitesi Sosyal Bilimler Enstitüsü. https://tez.yok.gov.tr/UlusalTezMerkezi/giris.jsp

Demircan, N., Ceylan A., 2003. Örgütsel güven kavramı: Nedenleri ve sonuçları. Celal Bayar Üniversitesi İ.I.B.F. Yönetim ve Ekonomi Dergisi. Cilt:10, Sayı:2. http://yonetimekonomi.cbu.edu.tr/dergi/pdf/C10S22003/ndac.pdf

Demirel, F., 2006. Sınıf öğretmenlerinin iş doyum düzeyleri (Denizli İli Örneği). Yayımlanmamış Yüksek Lisans Tezi. Pamukkale Üniversitesi Sosyal Bilimler Enstitüsü. https://tez.yok.gov.tr/UlusalTezMerkezi/giris.jsp

Duignan, P., \& Bezzina, M., 2006. Building a capacity for shared leadership in schools teachers as leaders of educational chance. Educational Leadership Conference, Wollongong: University of Wollongong.

Duman, C., 2006. Ortaöğretim kurumlarında görev yapan coğrafya öğretmenlerinin iş tatmini. Yayımlanmamış Yüksek Lisans Tezi. Marmara Üniversitesi Eğitim Bilimler Enstitüsü. https://tez.yok.gov.tr/UlusalTezMerkezi/giris.jsp

Dur, Ş., 2019. Sınıf öğretmenlerinde iş-yaşam dengesinin, örgütsel bağlllık ve iş doyumu ile ilişkisi. Yayımlanmamış yüksek lisans tezi, Yıldız Teknik Üniversitesi ve İstanbul Aydın Üniversitesi Sosyal Bilimler Enstitüleri Ortak Programı. https://tez.yok.gov.tr/UlusalTezMerkezi/giris.jsp

Eğinli, A. T., 2009. Çalışanlarda iş doyumu: Kamu ve özel sektör çalışanlarının iş doyumuna yönelik bir araştırma. Atatürk Üniversitesi İktisadi ve İdari Bilimler Fakültesi Dergisi, 23(3), 35-52.

Fields, D. L. and Blum, T. C., 1997. Employee Satisfaction Ġn Work Groups With Different Gender Composition. Journal of Organizational Behavior: The International Journal of Industrial, Occupational and Organizational Psychology and Behavior, 18(2), 181-196.

Firestone, W . A ., 1996. Leadership: Roles or functions? K . Leithvvood ve diğ. (eds.), International Flandbook of Educational Leadership and Administration, Netherlands: Kluwer Academic Publishers, , ss. 395-418. 
Gafa, İ., 2019. Sınıf öğretmenlerinin iş doyumu ve iş yaşamındaki yalnızlık düzeylerinin incelenmesi. Yayınlanmamış yüksek lisans tezi. Kırşehir Ahi Evran Üniversitesi Sosyal Bilimler Enstitüsü. https://tez.yok.gov.tr/UlusalTezMerkezi/giris.jsp

Gambetta, D., 1988. Can we trust, Trust: Making and breaking cooperative behaviors. D.G. Gambetta (Ed.), New York: Basil Blackwell, pp. 131-185.

Gibb, C. A., 1954. Leadership. In G. Lindzey (Ed.), Handbook of social psychology, 2, 877917.

Glenn N. D., Taylor R. D. , Weaver C. N., 1977. “Age and job satisfaction among males and females: A multivariate multi-study". Journal of Applied Psychology, Vol. 62, Pp.190-193. https://psycnet.apa.org/doi/10.1037/0021-9010.62.2.189

Gosling, J., Bolden, R. \& Petrov, G., 2009. Distributed Leadership in Higher Education: What Does It Accomplish?. Leadership, 5 (3), 299-310. https://doi.org/10.1177\%2F1742715009337762

Grant, C. P., 2011. The Relationship between Distributed Leadership and Principal's Leadership Effectiveness in North Carolina. Unpublished Doctoral Dissertation. The Graduate Faculty of North Carolina State University. Raleigh, North Carolina. https://eric.ed.gov/?id=ED530507

Gronn, P., 2002. Distributed leadership as a unit of analysis. Leadership Quarterly, 13, 42351. https://doi.org/10.1016/S1048-9843(02)00120-0

Gülay, S. S., 2018. Öğretmenlerin kayırmacılık algıları ile örgütsel güven düzeyleri arasındaki ilişkinin incelenmesi. Yayınlanmamış yüksek lisans tezi. Recep Tayyip Erdoğan Üniversitesi Sosyal Bilimler Enstitüsü https://tez.yok.gov.tr/UlusalTezMerkezi/giris.jsp

Gündoğdu, G. B., 2013. Sınıf öğretmenlerinin iş doyumu ve mesleki tükenmişlik düzeyleri üzerine bir çalışma: mersin ili örneği. Yayınlanmamış yüksek lisans tezi. Çăg Üniversitesi Sosyal Bilimler Enstitüsü https://tez.yok.gov.tr/UlusalTezMerkezi/giris.jsp

Güney S., 2017. Örgütsel Davranış. Ankara: Nobel Yayıncılık, 12-13.

Günüşen, Z. E., 2016. Örgütsel güvenin örgütsel bağlılık üzerindeki etkisi ve bir uygulama. Yüksek Lisans Tezi İstanbul Ticaret Üniversitesi Sosyal Bilimler Enstitüsü. https://tez.yok.gov.tr/UlusalTezMerkezi/giris.jsp

Gürbüz, R., 2012. Algılanan örgütsel destek ve örgütsel güvenin, örgütsel bağlılık ile ilişkisi. Yayınlanmamış yüksek lisans tezi. Atatürk Üniversitesi Sosyal Bilimler Enstitüsü. https://tez.yok.gov.tr/UlusalTezMerkezi/giris.jsp

Hackman, J. R., \& Oldham, G. R., 1975. Development of the job diagnostic survey. Journal of Applied psychology, 60(2), 159. https://psycnet.apa.org/doi/10.1037/h0076546

Harris, A. \& Spillane, J., 2008. Distributed leadership through the looking glass. Management in Education, 22, 22-31. https://doi.org/10.1177\%2F0892020607085623 Hoppock, R., 1935. Job Satisfaction, Harper and Brothers, New York, 47.

Hoy, W. K. \& Miskel, C. G., 2010. Eğitim yönetimi: Teori araştırma ve uygulama. Ankara: Nobel Yayınları. 
Hulpia, H. \& Devos, G., 2009. Exploring the link between distributed leadership and job satisfaction of school leaders, Educational Studies, 35(2), 153-171. https://doi.org/10.1080/03055690802648739

Hulpia, H., Devos G., \& Rosseel, Y., 2009. The relationship between the perception of distributed leadership in secondary schools and teachers' and teacher leaders' job satisfaction and organizational commitment. School Effectiveness and School Improvement: An International Journal of Research, Policy and Practice, 20 (3), 291-317. https://doi.org/10.1080/09243450902909840

Hulpia, H., Devos, G., Rosseel, Y., \& Vlerick, P., 2012. Dimensions of distributed leadership and the impact on teachers' organizational commitment: A study in secondary education. Journal of Applied Social Psychology, 42(7), 1745-1784. https://doi.org/10.1111/j.1559-1816.2012.00917.x

Hunt, J. and Saul, P., 1975. The relationship of age, tenure, and job satisfaction in males and females. Academy of Management Journal, 18, 690-702. https://doi.org/10.1080/00050067408256508

Işık, M., 2018. Yabancı diller yüksekokullarında görev yapan öğretim elemanlarımın paylaşılan liderlik davranışlarına ilişkin görüşleri. Yayımlanmamış yüksek lisans tezi, Dokuz Eylül Üniversitesi Eğitim Bilimler Enstitüsü. https://tez.yok.gov.tr/UlusalTezMerkezi/giris.jsp

İsmayılov, Ü., 2019. Öğretmenlerin duygusal zekâlarının örgütsel güvene etkisi. Yayınlanmamış yüksek lisans tezi. Necmettin Erbakan Üniversitesi Eğitim Bilimleri Enstitüsü. https://tez.yok.gov.tr/UlusalTezMerkezi/giris.jsp

Jacobs, G. E., 2010. The relationship between distributed leadership as practiced by principals and the organizational commitment of the teachers. Unpublished Doctoral Dissertation. Georgia Southern University, USA:

Kahveci, G., 2015. Okullarda Örgüt Kültürü, Örgütsel Güven, Örgütsel Yabancılaşma ve Örgütsel Sinisizm Arasındaki İlişkiler. Yayımlanmamış doktora tezi, Fırat Üniversitesi Eğitim Bilimleri Enstitüsü.

Katz, D. \& Kahn, R. L., 1966. The social psychology of organizations, New York: Wiley.

Kılınç, A. Ç., 2013. İlköğretim okullarında liderlik kapasitesinin belirlenmesi. Yayımlanmamış doktora tezi, Gazi Üniversitesi Eğitim Bilimler Enstitüsü.

Kim, J. B., 2019. A study on factors relevant to effects of shared leadership, organizational trust and job performance. Korea Convergence Society, KCI Accredited Journal. 10(7), 2019, 183-189.

Kocabaş, İ., \& Kartal, S. E., 2016. High school teachers' level of organizational trust. International Online Journal of Educational Sciences , vol.88, 217-226.

Korkmaz, A., 2019. Sınıf öğretmenlerinin örgütsel güven ve örgütsel muhalefet alg1 düzeyleri arasındaki ilişki. Yayınlanmamış yüksek lisans tezi. Maltepe Üniversitesi Sosyal Bilimler Enstitüsü. https://tez.yok.gov.tr/UlusalTezMerkezi/giris.jsp 
Korkmaz, E., 2011. İlköğretim okul yöneticilerinin paylaşımc liderlik davranışlarını gösterme düzeyleri. Yayımlanmamış yüksek lisans tezi, Sakarya Üniversitesi Sosyal Bilimler Enstitüsü. https://tez.yok.gov.tr/UlusalTezMerkezi/giris.jsp

Korkmaz, E. ve Gündüz, H. B., 2011. İlköğretim okulu yöneticilerinin dağıtımcı liderlik davranışlarını gösterme düzeyleri, Kalem Eğitim ve İnsan Bilimleri Dergisi, 1(1), 121153.

Koustelios, A. D., 2001. Personal characteristics and job satisfaction of greek teachers. International Journal of Educational Management, 15(7), 354-358. https://doi.org/10.1108/EUM0000000005931

Kovanc1, M., 2019. İlkokul öğretmenlerinin örgütsel güven algıları ile örgütlerine yabancılaşmaları arasındaki ilişki. Yayımlanmamış yüksek lisans tezi. Mersin Üniversitesi Eğitim $\quad$ Bilimleri $\quad$ Enstitüsü https://tez.yok.gov.tr/UlusalTezMerkezi/giris.jsp

Kösem, S. Ş., 2018. Öğretmenlerin paylaşılan liderlik davranışlarına ve bu davranışların okul müdürlerince uygulama düzeyine ilişkin görü̧̈leri. Yayımlanmamış yüksek lisans tezi, Çanakkale On sekiz Mart Üniversitesi Eğitim Bilimler Enstitüsü. https://tez.yok.gov.tr/UlusalTezMerkezi/giris.jsp

Kuzu, V., 2019. Sosyal bilgiler öğretmenlerinin boş zaman değerlendirme etkinlikleri ile mesleki iş doyumu arasındaki ilişki. Yayımlanmamış yüksek lisans tezi, Uşak Üniversitesi Sosyal Bilimler $\quad$ Enstitüsü. https://tez.yok.gov.tr/UlusalTezMerkezi/giris.jsp

Lapo, F. R. and Bueno, B. O., 2003. Professores, desencanto com a profissão e abandono do magistério. Cadernos de Pesquisa, 118, 65-88. https://doi.org/10.1590/S0100$\underline{15742003000100004}$

Locke, E. A., 1976. "The Nature and Causes of Job Satisfaction", in Dunette, M.(Ed), Handlook of Industrial and Organization Psychology, Rand McNally, Chicago, IL, 1300 .

Long, A., 2005. Happily ever after? A study of job satisfaction in Australia. Economic Record, 81(255), 303-321. https://doi.org/10.1111/j.1475-4932.2005.00271.x

Mishra, J., Morrisey, M. A., 1990. Trust in employee/employer relationships: A survey of West Michigan managers. Public Personnel Management, 19 (4), ss. 449. https://doi.org/10.1177\%2F009102609001900408

Oğuz, E., 2013. Yönetimde yeni yaklaşımlar, 2. Baskı (Ed. Yılmaz, K. ve Memduhoğlu, H., B.), Ankara: Pegem Akademi Yayınları.

Oldaç, Y İ., 2016. The relationship between distributed leadership, enabling school structure, teacher collaboration, academic optimism and student achievement: A school effectiveness model. Yayımlanmamış yüksek lisans tezi, Ortadoğu Teknik Üniversitesi Sosyal Bilimler Enstitüsü. https://tez.yok.gov.tr/UlusalTezMerkezi/giris.jsp

Ololube, N., 2006. Teachers job satisfaction and motivation for school effectiveness and assessment (pp. 60-87). University of Helsinki, Organizational Culture and Climate, Thousand Oaks, CA: Sage. 
Özdemir, M., 2012. Dağıtımcı liderlik envanterinin türkçe uyarlaması: Geçerlik ve güvenirlik çalışması, Kuram ve Uygulamada Ĕ̆itim Yönetimi (Educational Administration: Theory and Practice), 18(4), 575-598. https://pegem.net/dosyalar/dokuman/137539-20130222131213-4.pdf

Özdevecioğlu, M., 2003. İş tatmini ve yaşam tatmini arasındaki ilişkinin belirlenmesine yönelik bir araştırma. Ulusal Yönetim ve Organizasyon Kongresi, 1, 90-97.

Özdöl, M. F., 2008. Konya ilinde görev yapan ortaöğretim fizik öğretmenlerinin motivasyonu ve iş tatminlerinin araştııılması. Yayınlanmamış Doktora Tezi. Selçuk Üniversitesi Fen Bilimleri Enstitüsü. https://tez.yok.gov.tr/UlusalTezMerkezi/giris.jsp

Özer, N. ve Beycioğlu, K., 2013. Paylaşılan liderlik ölçeğinin geliştirilmesi: Geçerlik ve güvenirlik çalışmaları. İlköğretim Online, 12(1), 77-86.

Özer, N., Demirtaş, H., Üstüner, M. ve Cömert, M., 2006. Ortaöğretim öğretmenlerinin örgütsel güven algiları. Ege Eğitim Dergisi, (7)1, 103-124.

Özgen, H., Yalçın. A., 2011. İnsan kaynakları yönetimi stratejik bir yaklaşım. Nobel Kitapevi, Adana, ss. 330-332.

Perry, M. L., Pearce, C. L. \& Sims. Jr., H., 1999. Empowered selling teams: How shared leadership can contribute to selling team outcomes, Journal of Personal Selling $\mathcal{E}$ Sales Management, 19(3), 35-51.

Ray, H., 2019. Okullarda paylaşılan liderlik uygulamaları ile öğretmenlerin örgütsel güven düzeyleri arasındaki ilişki. Yayınlanmamış yüksek lisans tezi. Uşak Üniversitesi, Sosyal Bilimleri https:/tez.yok.gov.tr/UlusalTezMerkezi/giris.jsp

Samadov, S., 2006. İş doyumu ve örgütsel bağlllık: Özel sektörde bir uygulama. Yayınlanmamış yüksek lisans tezi. Dokuz Eylül Üniversitesi, Sosyal Bilimleri Enstitüsü. https://tez.yok.gov.tr/UlusalTezMerkezi/giris.jsp

Sarıçiçek, L., 2014. Gaziantep ili Şehitkâmil ilçesindeki ilkokullarda öğretmen görüşlerine göre paylaşılan liderlik ve okul iklimi. Yayımlanmamış yüksek lisans tezi, Zirve Üniversitesi Sosyal Bilimleri $\quad$ Enstitüsü. https://tez.yok.gov.tr/UlusalTezMerkezi/giris.jsp

Sarıkaya, Ş., 2019. Öğretmenlerin iş doyumunun yordayıcısı olarak örgütsel güven ve örgütsel destek algısı. Yayınlanmamış yüksek lisans tezi. Marmara Üniversitesi ve İstanbul Sabahattin Zaim Üniversitesi Eğitim Yönetimi ve Denetimi Ortak Programı. https://tez.yok.gov.tr/UlusalTezMerkezi/giris.jsp

Sarpkaya, R., 2000. Liselerde çalışan öğretmenlerin iş doyumu. Amme İdaresi Dergisi, 33(2), 111-124.

Saruhan, C., 2019. Eğitim örgütlerinde örgütsel adalet ve örgütsel güven arasındaki ilişki. Yayınlanmamış yüksek lisans tezi. Harran Üniversitesi, Sosyal Bilimleri Enstitüsü. https://tez.yok.gov.tr/UlusalTezMerkezi/giris.jsp

Saruhan, Ş. C.; Özdemirci, A. (2013). Bilim, felsefe ve metodoloji. İstanbul: Beta Basım 
Seashore Louis, K., Dretzke, B., \& Wahlstrom, K., 2010. How does leadership affect student achievement? Results from a national us survey, School Effectiveness and School Improvement, 21(3), 315-336.

Serdar, A., 2019. Sivil toplum örgütlerinde gönüllü çalışanların örgüt iklimi algılarının örgütsel güven üzerine etkisi. Yayınlanmamış yüksek lisans tezi. Bahçeşehir Üniversitesi Sosyal Bilimler Enstitüsü. https:/tez.yok.gov.tr/UlusalTezMerkezi/giris.jsp

Silah, M., 2003. Sanayi İşletmelerinde Önemli ve Çağdaş Bir Gereksinim: Süreç Danışmanlığı Uygulamaları. Çukurova Üniversitesi Sosyal Bilimler Dergisi, 26 (1), 143-168. http://www.kamu-is.org.tr/pdf/7227.pdf

Smith, F. J., 1977. Work attitudes as predictors of attendance on a specific day. Journal of Applied Psychology, 62, (1), 16. https://psycnet.apa.org/doi/10.1037/0021$\underline{9010.62 .1 .16}$

Song, J. S., 2019. The effect of shared leadership on organizational trust, knowledge sharing and innovative behavior. Korea Convergence Society, KCI Accredited Journal. 10(7), 2019, 485-500. https://doi.org/10.5392/JKCA.2019.19.09.485

Spillane, J. P., 2006. Distributed leadership, San Francisco: Jossey-Bass.

Spillane, J. P., Camburn, E. M. \& Amber Stitziel Pareja, A. S., 2007. Taking a distributed perspective to the school principal's workday, Leadership and Policy in Schools, 6(1), 103-125. https://doi.org/10.1080/15700760601091200

Şakacı, E., 2019. Psikolojik şiddetin iş doyumu üzerindeki etkisi. Yayınlanmamış yüksek lisans tezi. Gazi Üniversitesi Sosyal Bilimler Enstitüsü. https://tez.yok.gov.tr/UlusalTezMerkezi/giris.jsp

Tan, H. H., \& Tan, C. S., 2000. Toward the Differentiation of Trust in Supervisor and Trust in Organization. Genetic, Social, and General Psychology Monographs, 126(2): 241.

Taş, A., ve Önder, E., 2010. Yöneticilerin liderlik davranışlarının personel iş doyumuna etkisi. Elektronik Sosyal Bilimler Dergisi, 9, (32), 18.

Taşdan, M., 2008. Kamu ve özel ilköğretim okullarında görevli öğretmenlerin değer, iş doyumu ve öğretmene mesleki sosyal destek ile ilgili görüşleri (Yayınlanmamış Doktora Tezi). Ankara Üniversitesi, Eğitim Bilimleri Enstitüsü, https://tez.yok.gov.tr/UlusalTezMerkezi/giris.jsp

Taşdan, M. ve Oğuz, E., 2013. İlköğretim öğretmenleri için dağıtımcı liderlik ölçeğinin geçerlik ve güvenirlik çalışması, Kafkas Üniversitesi Sosyal Bilimler Enstitü Dergisi, 1(11), 103-124. https://www.kafkas.edu.tr/dosyalar/sobedergi/file/011/8 0.pdf

Tengilimoğlu, D., 2005. Hizmet işletmelerinde liderlik davranışları ile iş doyumu arasındaki ilişkinin belirlenmesine yönelik bir araştırma. Ticaret ve Turizm Ĕ̆itim Fakültesi Dergisi. 1, 23-45.

Theodossiou, I. and Vasileiou, E., 2007. Making the risk of job loss a way of life: Does it affect job satisfaction? Research in Economics, 61(2), 71-83. https://doi.org/10.1016/j.rie.2007.03.002 
Topaloğlu, I. G., 2010. İş görenlerin adalet ve etik algıları açısından örgütsel güven ile örgütsel bağlllık ilişkisi. Yayınlanmamış yüksek lisans tezi. Atılım Üniversitesi Sosyal Bilimler Enstitüsü. https://tez.yok.gov.tr/UlusalTezMerkezi/giris.jsp

Tschannen-Moran, M., \& Hoy, W., 1998. Trust in schools: A conceptual and empirical analysis. Journal of Educational Administration, 36(4), 334-352. https://doi.org/10.1108/09578239810211518

Ulusoy, T., 2014. Okullarda sergilenen dağıtımcı liderlik davranışları ile öğretmenlerin iş doyumu ve örgütsel adanmışlıkları arasındaki ilişkiler. Yayınlanmamış yüksek lisans tezi. Gaziosmanpaşa Üniversitesi Eğitim Bilimler Enstitüsü. https://tez.yok.gov.tr/UlusalTezMerkezi/giris.jsp

Uslu, B., Beycioğlu, K., 2013. İlköğretim okulu öğretmenlerinin örgütsel bağlllıkları ile müdürlerin paylaşılan liderlik rolleri arasındaki ilişki. Ondokuz Mayıs Üniversitesi Eğitim Fakültesi Dergisi, 32(2), 323-345.

Watson, A. J., Hatton, N. G., Squires, D. S. \& Soliman, I. K., 1991. School staffing and the qualitiy of education: Teacher adjustment and satisfaction. Teaching and Teacher Education. 7 (1), 63-77. https://doi.org/10.1016/0742-051X(91)90058-W

Weiss, C. H.; Cambone, J., 1994. Principals, shared decision making, and school reform. Educational Evaluation and Policy Analysis, 16, 287-301. https://doi.org/10.3102\%2F01623737016003287

Wood, M. S., 2005. Determinants of shared leadership in management teams. International Journal of Leadership Studies, 1(1), 64-85.

Wood, M. S. \& Fields, D., 2007. Exploring the impact of shared leadership on management team member job outcomes. Baltic Journal of Management, 2 (3), 251272. https://doi.org/10.1108/17465260710817474

Yener, S., 2014. Özel ortaöğretim kurumlarında paylaşılan liderlik davranışı ve işten ayrılma niyeti arasındaki ilişkide psikolojik güvenlik algısının aracı değişken ilişkisinin araştırılması. Yayınlanmamış doktora tezi, Haliç Üniversitesi Sosyal Bilimleri Enstitüsü. https://tez.yok.gov.tr/UlusalTezMerkezi/giris.jsp

Y1ldız, P., 2019. Örgütsel bağlllık üzerinde örgütsel güven ve örgütsel iletişimin etkisini belirlemeye yönelik bir araştırma. Yayınlanmamış yüksek lisans tezi. Marmara Üniversitesi Sosyal Bilimler Enstitüsü. https:/tez.yok.gov.tr/UlusalTezMerkezi/giris.jsp

Yılmaz, A. İ., 2013. İlköğretim okulu öğretmenlerinin paylaşılan liderlik davranışları. Yayımlanmamış yüksek lisans tezi, Dokuz Eylül Üniversitesi Eğitim Bilimleri Enstitüsü. https://tez.yok.gov.tr/UlusalTezMerkezi/giris.jsp

Yılmaz, D., 2014. Dağıtılmış liderliğin örgütsel güven ile algılanan örgütsel destek ve okul başarısıyla ilişkisi. Yayınlanmamış doktora tezi. Eskişehir Osmangazi Üniversitesi Eğitim Bilimleri Enstitüsü. https://tez.yok.gov.tr/UlusalTezMerkezi/giris.jsp

Yılmaz, D. ve Turan, S., 2015. Dağıtılmış liderliğin okullardaki görünümü: Bir yapısal eşitlik modelleme çalışması. Kuram ve Uygulamada Eğitim Yönetimi, 21(1), 93-126. http://www.kuey.net/index.php/kuey/article/view/kuey.2015.005 
Yılmaz, E., 2006. Okullardaki örgütsel güven düzeyinin okul yöneticilerinin etik liderlik özellikleri ve bazı değişkenler açısından incelenmesi. Yayımlanmış doktora tezi. Selçuk Üniversitesi Sosyal Bilimler Enstitüsü. https://tez.yok.gov.tr/UlusalTezMerkezi/giris.jsp

Yılmaz, Ş., 2019. İlk ve ortaokul öğretmenlerinin örgütsel güven düzeylerinin iş doyumuna etkisi. Marmara Üniversitesi ve İstanbul Sabahattin Zaim Üniversitesi Eğitim Yönetimi ve Denetimi Ortak Programı. https://tez.yok.gov.tr/UlusalTezMerkezi/giris.jsp

Yukl, G., 2002. Leadership in organizations (5th Ed.). Upper Saddle River, NJ: Prentice-Hall. 

will be applied to their work. Under the terms of this license, no permission is required from the author(s) or publisher for members of the community to copy, distribute, transmit or adapt the article content, providing a proper, prominent and unambiguous attribution to the authors in a manner that makes clear that the materials are being reused under permission of a Creative Commons License. Views, opinions and conclusions expressed in this research article are views, opinions and conclusions of the author(s). Open Access Publishing Group and European Journal of Education Studies shall not be responsible or answerable for any loss, damage or liability caused in relation to/arising out of conflicts of interest, copyright violations and inappropriate or inaccurate use of any kind content related or integrated into the research work. All the published works are meeting the Open Access Publishing requirements and can be freely accessed, shared, modified, distributed and used in educational, commercial and non-commercial purposes under a Creative Commons Attribution 4.0 International License (CC BY 4.0). 